\title{
The Role of Legal Culture in Maintaining Social Stability and Countering Separatist Movements: Case of Ukraine
}

\author{
Vira Kachur ${ }^{1}$, Liudmyla Protosavitska ${ }^{2}$, Liudmyla Zasukha ${ }^{3}$, Liudmyla Golovko ${ }^{4}$
}

\begin{abstract}
This article develops hypotheses that raising the level of legal culture can serve as an effective instrument in maintaining sustainable development, social stability and territorial integrity. Legal culture should be considered as a regulator and stabilizer of social relations, both in individual countries and at the international level. It is necessary to consider legal culture in conjunction with morality, ethical, economic and political values and priorities. The study has concluded that creation of the democratic state of law and civil society is impossible without raising the level of legal culture. Creation of a strategy for raising the level of legal culture of the population is becoming a priority task, since it will allow forming the functions of the legal culture in the implementation of the national security policy in the socio-economic, political and regional spheres, preserving historical heritage and territorial integrity of Ukraine, overcoming internal and external threats to its stable state and legal development.
\end{abstract}

Keywords: Legal culture, legal awareness, social stability, sustainable development

\section{Introduction}

Challenges of time caused by social manifestations (unemployment, labor migration, depreciation of labor, weak social dialogue and social cohesion) and events (military conflicts, separatist movements) of recent years in the world and in Ukraine in particular created the need to rethink the role and importance of state and legal phenomena in public life. Legal culture plays an important role not only in the formation of civil society, but also in ensuring social stability and territorial integrity of the state.

In Ukraine the state of legal consciousness and legal culture of society as a whole and of the individual in particular does not meet the European standards, resulting in people's indifference to legal values, lack of needs and skills to apply the rules of law, which leads to the emergence of illegitimate behavior and offenses and even separatist movements. In connection with the increase in the number of offenses, the need for the preventive and educational functions of the legal culture is being updated (Khomyshyn, 2014).

The manifestations of separatist movements is not only an internal problem of a particular country. They also affect regional security, creating regional conflicts

${ }^{1} \mathrm{PhD}$., associate professor, head of the Department of State and Law of the National University of Life and Environmental Sciences of Ukraine

${ }^{2} \mathrm{PhD}$, associate professor of the Department of State and Law of the National University of Life and Environmental Sciences of Ukraine

${ }^{3}$ PhD., Researcher of the National Academy of Agrarian Sciences of Ukraine

${ }^{4} \mathrm{PhD}$., associate professor of the Department of International Law and Comparative Law of the National

University of Life and Environmental Sciences of Ukraine 
(Ladychenko, 2017). Separatist processes represent a threat to national security as they are directly related to the issues of changing borders and the existence of the country as such. That is why an important task of the modern state is to formulate a strategy and determine effective methods to counter the secessionist processes. Raising the level of legal culture of population can serve as an effective instrument in countering separatist movements. Legal culture is a significant factor in social stability. It contributes to creation of democratic state of law - a state in which citizens know the laws and enforce them, in which the development of the state is predictable, and its citizens feel confident in the future and are socially protected.

\section{Separatist Movements in the Modern World: International Legal Dimensions, Causes and Methods of Combating}

According to international relations theory, separatism (from latin separatus separation) is a movement aimed at secession of a part of the state's territory and population. Separatism often provides the ultimate goal of complete independence from an existing country (for example, the independence of Norway from Sweden of 1905, Finland from Russia of 1917, Iceland from Denmark of 1944, Bangladesh from Pakistan of 1971). One of the types of separatism is irredentism, that is, the desire to separate territory and population from one state and to become part of another state (the socalled Turkish Republic of Northern Cyprus, calls of extremist elements in Abkhazia to withdraw from Georgia and join the Russian Federation). Separatism can also aim at achieving, strengthening, or maintaining political autonomy within an existing country.

The approach to the problems of separatism from the point of view of international law is complicated by the conflict of its fundamental principles: on the one hand, the inviolability of borders and respect for the territorial integrity of states, on the other hand - the right of all people to self-determination. The doctrine of self-determination of peoples became the norm of international law in 1919 under the Versailles diplomatic system. The principle of self-determination declared in United Nations Declaration, Declaration on the Granting of Independence to Colonial Countries of 1960 and Friendly Relations Declaration of 1970 remains unchanged in international law to this day. However, these documents provide for the right to self-determination leading to succession as a matter of last resort only, in extreme situations, to colonized and severely persecuted peoples. In other instances of attempted secession, where the relevant people is not oppressed, as in Quebec or Scotland, international law is neutral on secession - it does not support a right to secession nor does it prohibit secession. Instead, the secessionist dispute is left to the realm of domestic law and to political negotiations between the mother state and the secessionist entity (Sterio, 2018). The term "people" for the purposes of self-determination entails a subjective element, such as a common belief by members of the group that they share the same characteristics and beliefs and thus form a common unit, as well as an objective element, such as common racial background, culture, ethnicity, religion, language, and history (Scharf, 2003).

Absolutization of the principle of inviolability of borders and respect for the territorial integrity of states can lead to the preservation of internal conflicts and international conflicts, while absolutization of the right to self-determination promotes the 
uncontrolled process of the emergence of a large number of newly formed states, some of which may be unviable and become objects of manipulation of other states, will inevitably generate new conflict situations. Modern views on the problems of human rights, ethnic, religious minorities require a revision of the collective view on separatism as a purely internal affairs of individual states, require the development of new criteria and evaluation, adequate mechanisms and principles of the approach of the UN, regional organizations, the international community as a whole to the problems of separatism in order to find ways for their just and peaceful solution (Grin, 2010).

The center of separatism is formed under the influence of a complex of closely interrelated factors. The following main causes of separatism can be distinguished:

- ethnic heterogeneity, which is the most common cause of separatism (for example, Basque Country in Spain, Abkhazia and South Ossetia in Georgia);

- religious heterogeneity (for example, Kashmiri Muslims want to unite with Pakistan); - economic and geographical factors (for example, Italy's separatist Northern League); - internal political factors: desire of regional elites for power (for example, North and South Korea);

- foreign policy factors: the support of separatists on the part of world leaders and stronger neighboring countries (for example, outside support contributed to the breakup of Yugoslavia).

- migration, rise of intolerance as a new factor of separatism movements in Europe and Asia (Baranov, 2005).

Scientists distinguish new forms of separatism in Europe - separatism of "white Europeans", respectively traditional majority European nations, ethnic or religious communities in reaction to the existence of new minorities (Bötticher, 2013). Professor Jaime Nogueira Pinto claims that the main causes for the recent rise in regional separatist movements throughout Europe are interconnected. The growth of Muslim immigration (mainly in the largest EU countries - France, Germany, Italy and the United Kingdom but also in some of the Nordic and Benelux countries) is perceived as a threat to national identity, employment and security. Restricting such immigration has become a key political issue, fostering the growth of right-wing political movements. Globalization, with its tendency to move industries and jobs to lower-cost locations, especially in Asia, as well as competition from immigrants willing to work for lower wages, have made protectionism more appealing to Western Europeans (Pinto, 2017).

According to Matthias Bieri, the EU plays an important role in contemporary independence movements, as their aim is to create an independent state within the EU. In the eyes of many regionalists, the principle of subsidiarity as anchored in the Maastricht Treaty makes the EU a guarantor of far-reaching regional competences. Dreams of self-determination have further been fuelled by the vision of overcoming the nation-state in a unified Europe (Bieri, 2014). Seth Jolly argues that increased European integration actually encourages regionalist parties to enter political competition and, by making these parties more viable, increases the likelihood of success in those elections which can present a significant political threat to national leaders (Jolly, 2007). Consequently, the issue of countering separatism is more relevant for the EU member states as it was before. 


\section{Separatist Movements in Ukraine}

Comparing the factors of the emergence of separatism in Ukraine with the tendencies in other states, Ukrainian researchers emphasize that separatism in the East of Ukraine has a number of peculiarities. Firstly, it is not the result of intrastate conflict on interethnic, interfaith or other grounds. Throughout the history of independent Ukraine, systematic organized separatist movements with recognized leaders and broad support from the population were not observed in this territory, and there are no areas of compact residence of representatives of ethnic or confessional groups (Kosilova, 2017). Secondly, the ideological foundations of separatist movements were developed outside of Ukraine in the form of the project "Russian World" (Reznikova, 2016). Analyzing the reasons for the deployment of separatist processes in Ukraine, it should be noted that the purposeful ideological and informational activity of the Russian Federation and its agents in Ukraine played a major role in this movements in order to undermine the national unity and legitimacy of the Ukrainian state. In particular, the informational influence of the Russian Federation against the background of weak economic development and subsidization of the region has become one of the important factors that led to the emergence of separatist moods in the Eastern region and the Autonomous Republic of Crimea.

According to O. Karpets, the reasons for the emergence of separatism in the East of Ukraine also belong to the social-class component. A significant amount of the population of the uncontrolled part of the Donbas, at least at the beginning of the conflict, believed that they opposed the prevailing in Ukraine striking social injustice, against political and property inequality, and finally against the exploiting class for some just, without human exploitation (Karpets, 2017). Thus, joining the Russian Federation seemed part of the population of the Donetsk and Lugansk regions to improve their financial situation and was associated with the return to the former USSR.

\section{Legal Culture as a Factor in Countering Separatist Movements}

Building a civil society in Ukraine that respects the laws and rights of one another is closely linked to raising citizens' legal awareness and their legal culture (Ladychenko, 2019). The legal culture of an individual means legal education of a person, including legal awareness, the ability and skills to use the law, subordination of their behavior to the requirements of legal norms (Golovko, 2019). Unfortunately, the legal culture of the citizens of Ukrainian society desires to be better and is still in the process of forming the beginnings of a democratic, legal culture (Yara, 2018). The legal culture of society is a set of factors that characterize the level of justice, the perfection of legislation, the organization of its compliance, the state of law and order. The legal culture of an individual is characterized by a general respect for the law, sufficient knowledge of the content of its norms and the ability to implement them.

Legal education has the biggest influence on the formation of legal culture. Legal education - purposeful, consistent, systematic activity of the state and its bodies, as well as nongovernmental organizations in forming the legal system of legal knowledge. Skills, legal thinking, legal feelings - a sense of law, legality, a sense of respect for law, to those 
social values that are regulated and protected by law and legislation.

Legal education consists of the following parts:

- tasks that should promote legitimacy and social stability in society (Ladychenko, 2018);

- principles: systematicity, continuity of implementation, purposefulness, consistency, provision with both certain means and trained personnel (Gulac, 2019);

- forms, among which are: legal education (training), which is the most effective and effective form, since it gives a certain system of legal knowledge; legal advocacy - the dissemination of certain legal ideas and legislation among a large population; legal agitation - dissemination of legal ideas and knowledge among a small population; legitimate socially active activity - carried out practically in the process of implementation of legal norms; self-education;

- content - legal knowledge and to what extent it should be given (Vedernikov, 2005).

The development of the state is impossible without the legal culture of each its citizen, which determines universal respect for law in society, the cultivation of the rule of law and, therefore, the real functioning of all other institutions of the state. Raising the level of legal culture of the population of Ukraine at the present stage is very important, since recent events in the country created the need for each person to apply their legal awareness in practice, adhere to the law, be able to realize their actions and guide them, direct their efforts to the awakening of patriotism and actions associated with it.

\section{Conclusions}

Scientists highlight non-violent and violent methods used by states to preserve territorial integrity. Among the methods that are listed, we do not find an increase in the level of the legal culture of the population, which is understood as the system of attitudes and perceptions that determine the behavior and activities of people in the legal sphere. Raising the level of legal culture of the population can serve as an effective preventive factor in countering separatist movements. It is necessary to maximally strive to use nonviolent political methods, intensify information policy in problem regions, explaining the advantages of the country's territorial integrity, the formation of legal values among the population, contributing to its legal development and reducing the number of actions that are contrary to the law.

\section{References}

Baranov, A. (2005). Separatism in the modern world: the political-territorial aspect. Human. Community. Control, 3, 108-123.

Bieri, M. (2014). Separatism in the EU. Retrieved from: https://css.ethz.ch/content/dam/ethz/specialinterest/gess/cis/center-for-securities-studies/pdfs/CSSAnalyse160-EN.pdf

Bötticher, A., Mares, M. (2013). Conceptualizing New Forms of Separatism in Europe. Conference proceeding of the the 7th ECPR General Conference Panel "State of Unions: Separatism and Crisis of National Unity in Time of EUs Crisis" Bordeaux 4-7 September 2013. Retrieved from: https:/ / ecpr.eu/Filestore/PaperProposal/3dc79fac-fb1c-4576-8dc6-2c3758362768.pdf

Golovko, L., Yara, O., Kutsevych, M., Hubanova, T. (2019). Environmental Policy Integration in Ukraine and the EU European Journal of Sustainable Development, Volume 8, № 3, 221-227

Grin, A.A. (2010). Dictionary of international legal terms. Uzhhorod: Private Publishing House Danilo S.I. 
Gulac, O., Dubchak, L., Iarmolenko, I., Yanchuk, J. (2019). Cooperation of Ukraine and the European Union in the ecological sector: directions and prospects. European Journal of Sustainable Development, Volume 8, № 1, 22-30.

Jolly, S. (2007). How the EU Fuels Sub-National Regionalism. Retrieved from: https://www.researchgate.net/publication/242478463_How_the_EU_Fuels_Subnational_Regionalism

Karpets, O. (2017). Separatism in Ukraine and its social cause. Retrieved from: http://informat.com.ua/uk/gromadjanskij-konflikt-ta-socialni-koreni-separatizmu-v-ukraini/

Khomyshyn, I. (2014). The Role of Legal Culture in Maintaining Order in Society. Bulletin of the National University 'Lviv Polytechnic", 810, 105-109.

Kosilova, O. (2017). Separatism in Ukraine: precautions, causes, ways of countering and normative-legal regulation of counteraction. Constitutional and legal academic studies, 4, 19-27.

Ladychenko, V., Golovko, L. (2018). The Right of Access to Environmental Information in Ukraine and the EU European Journal of Sustainable Development, Volume 7, № 3, 455-459

Ladychenko, V., Melnychuk, O., Yara, O., Kanaryk J. (2019). International Mechanism of the Environmental Information Access and Cooperation Framework for Climate Change Protection European Journal of Sustainable Development, Volume 8, № 4, 131-139

Ladychenko, V., Golovko, L. (2017). Implementation of European Environmental Policy in Ukraine: Problems and Prospects. European Journal of Sustainable Development, Volume 6, № 3, 333-339

Pinto, J.N. (2017). Opinion: Separatism in Europe. Retrieved from: https://www.gisreportsonline.com/opinion-separatism-in-europe,politics,2510.html

Reznikova, O., Driomov, S. (2016). Some legislative aspects of countering separatism in Ukraine. Strategic priorities, 3(40), 18-25.

Scharf, M.P. (2003). Earned Sovereignty. Judicial Underpinnings, 31, 373-79.

Sterio, M. (2018). Self-Determination and Secession Under International Law: The Cases of Kurdistan and Catalonia. Law Faculty Articles and Essays, 917. Retrieved from: https://engagedscholarship.csuohio.edu/fac_articles/917

Vedernikov, Y. (2005). Theory of state and law. Kiev: Center for Educational Literature.

Yara, O., Uliutina, O., Golovko, L., Andrushchenko L. (2018). The EU Water Framework Directive: Challenges and Prospects for Implementation in Ukraine European Journal of Sustainable Development, Volume 7, № 2, 175-182 